\title{
The effects of local nitroglycerin on the surgical delay procedure in prefabricated flaps by vascular implant in rats ${ }^{1}$
}

\author{
Efeitos da nitroglicerina tópica na autonomização de retalhos \\ pré-fabricados por implante vascular em ratos
}

\begin{abstract}
Jairo Zacchê de SáI, José Lamartine de Andrade Aguiar ${ }^{\mathrm{II}}$, Adriana Ferreira Cruz ${ }^{\mathrm{III}}$, Alexandre Ricardo Pereira Schuler ${ }^{\mathrm{IV}}$, José Ricardo Alves de Limav', Olga Martins Marques ${ }^{\mathrm{VI}}$
\end{abstract}

IFellow PhD degree, Postgraduate Program in Surgery, UFPE, Recife-PE, Brazil. Conception, design, acquisition and interpretation of data; manuscript writing.

IIAssociate Professor; Department of Surgery, Postgraduate Program in Surgery, UFPE, Recife-PE, Brazil. Conception and design of the study.

IIIVeterinarian, CES, Department of Surgery, UFPE, Recife-PE, Brazil. Control of pre, peri and postoperative of the animals.

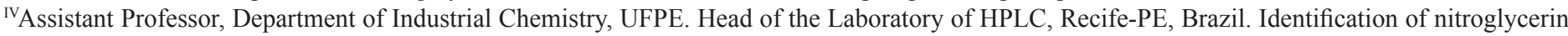
and its metabolites.

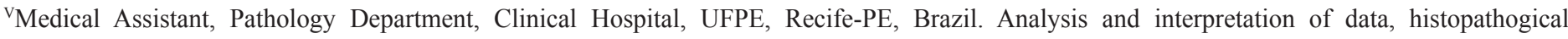
examinations.

IIIAssistant Professor, Department of Nutrition, UFPE, Recife-PE, Brazil. Interpretation of data, analysis of blood samples.

\section{ABSTRACT}

PURPOSE: To evaluate the effect of local nitroglycerin on the viable area of a prefabricated flap for vascular implant in rats, and to investigate the surgical delay procedure.

METHODS: A femoral pedicle was implanted under the skin of the abdominal wall in forty Wistar rats. The animals were divided into four groups of ten: group 1 - without surgical delay procedure and local nitroglycerin; group 2 - with surgical delay procedure, but without local nitroglycerin; group 3 - without surgical delay procedure, but with local nitroglycerin; and group 4 - with simultaneous surgical delay procedure and local nitroglycerin. The percentages of the viable areas, in relation to the total flap, were calculated using AutoCAD R 14.

RESULTS: The mean percentage value of the viable area was $8.9 \%$ in the group $1.49 .4 \%$ in the group $2 ; 8.4 \%$ in the group 3 and $1.1 \%$ in the group 4. There was significant difference between groups 1 and $2(p=0.005), 1$ and $4(p=0.024), 2$ and 3 ( $p=0.003), 2$ and $4(\mathrm{p}=0.001)$. These results support the hypothesis that the closure of the arterial venous channels is responsible for the phenomenon of surgical delay procedure.

CONCLUSION: Local nitroglycerin did not cause an increase in the prefabricated viable flap area by vascular implantation and decreased the viable flap area that underwent delay procedures.

Key words: Surgical Flaps. Nitroglycerin. Rats.

\section{RESUMO}

OBJETIVO: Avaliar o efeito da nitroglicerina tópica sobre a área viável de um modelo de retalho pré-fabricado por implante vascular em ratos e analisar o mecanismo de autonomização cirúrgica aplicada a retalhos pré-fabricados.

MÉTODOS: Foram utilizados 40 ratos Wistar. No primeiro tempo cirúrgico - 20 ratos foram submetidos a implante do pedículo femoral na região subdérmica da parede abdominal, e 20 submetidos à autonomização cirúrgica de retalho cutâneo de parede abdominal e, simultaneamente, implante do pedículo femoral na região subdérmica deste retalho. No segundo tempo - após três semanas e em todos os animais, era elevado um retalho cutâneo ilhado, pediculado unicamente nos vasos implantados e divididos em quatro grupos de dez animais: grupo 1, com retalhos submetidos unicamente a implante do pedículo femoral na região subdérmica da parede abdominal; grupo 2, com retalhos submetidos à autonomização cirúrgica e implante do pedículo femoral na região subdérmica deste retalho; 
grupo 3, com retalhos submetidos unicamente a implante do pedículo femoral na região subdérmica da parede abdominal tratados com nitroglicerina tópica; grupo 4, com retalhos submetidos à autonomização cirúrgica e implante do pedículo femoral na região subdérmica deste retalho tratados com nitroglicerina tópica. O percentual de área viável, em relação à área total do retalho, foi calculado sete dias após o segundo tempo cirúrgico.

RESULTADOS: O valor médio de área viável alcançou 8,9\% no grupo 1; 49,4\% no grupo 2; 8,4\% no grupo 3; e 1,1\% no grupo 4. Houve diferença significante entre os grupos 1 e $2(p=0,005) ; 1$ e $4(p=0,024) ; 2$ e 3 ( $p=0,003)$ e 2 e 4 ( $p=0,001)$. Os resultados fortaleceram a hipótese de que o fechamento dos canais arteriovenosos é o principal mecanismo responsável pelo aumento da área viável observada em retalhos submetidos à autonomização cirúrgica.

CONCLUSÃO: A nitroglicerina tópica não induziu ao aumento da área viável dos retalhos pré-fabricados por implante vascular e diminuiu a área viável dos retalhos submetidos à autonomização.

Descritores: Retalhos Cirúrgicos. Nitroglicerina. Ratos.

\section{Introduction}

The need to manufacture safer cutaneous flaps has led to the investigation of survival mechanisms and the identification of substances that may improve the survival of these flaps ${ }^{1-4}$.

Nitroglycerin is a potent vasodilator and its sublingual use has been mentioned in the literature since $1879^{5,6}$. Although it is absorbed through the epithelium there is no report of the local effect of nitroglycerin on the perfusion of pre-fabricated flaps by vascular induction.

Different from the conflicting results observed when medication is used to improve the viability of the flaps, the surgical delay procedure provides an increase in the viable area of cutaneous flaps in an effective and reliable manner ${ }^{7-12}$. However, this makes the surgical procedure longer. It is worth pointing out that, in emergency situations, such as those involving trauma, or when the surgical plan has to be modified during the operation, the flap cannot be subjected to the delay procedure earlier.

If the phenomenon of the surgical delay procedure was fully understood, the information could be used to bring on the phenomenon chemically, providing immediate protection for a flap that is at risk. Pharmacological studies have thus been used, not only to preserve an intrinsically weakened flap, but also to test hypotheses concerning the phenomenon of surgical delay procedure, and to improve understanding of the physiopathology of intrinsic failure of cutaneous flaps ${ }^{1-4,13}$

Sá et $a l^{7}$ have observed, in rats, that flaps undergoing the surgical delay procedure and simultaneously the implant of a vascular pedicle presented a significantly greater viable area compared with those that did not undergo the procedure. It was also observed that there was no significant difference in the number of vessels formed around the implanted pedicle, whether the flap was subjected to the surgical delay procedure or not.

The aim of this study was to evaluate the vasodilator effect of local nitroglycerin on the surgical delay procedure mechanism, and its action on the viable area of a prefabricated flap model for vascular implant in rats.

\section{Methods}

Forty male Wistar rats, 12 weeks old, were randomly divided into four groups and housed at the UFPE's Experimental Surgery Unit, where the surgical procedures were carried. The animals were anesthetized with $10 \%$ chloral hydrate at a dose of $0.4 \mathrm{~mL} / 100 \mathrm{~g}$ of body weight intraperiotoneally ${ }^{14}$. The surgical procedures were carried out under strictly aseptic and anti-septic conditions.

\section{Vascular pedicle implant}

The superficial femoral artery and vein were dissected along with the nerve and a layer of muscle, using a surgical microscope $\mathrm{dfv}^{\circledR}$. Then, the vasculo-nervous pedicle was tied distally, sectioned, and proximal segment was rotated along with a layer of muscle surrounding it, implanted in the subdermal region of the abdominal wall and fixed in place with 6-0 nylon, and the incisions were closed with 5-0 nylon (Figure 1). Twenty animals underwent only the implant of a femoral pedicle in the subdermal region of the abdominal wall.

The flaps undergoing a surgical delay procedure then had the pedicles dissected exactly as before. However, a large cranial-based cutaneous flap was raised in the abdominal wall. The previously dissected pedicle was then implanted in this flap by way of a subcutaneous tunnel and fastened in place with 6-0 nylon. Once the pedicle had been fixed in place the flap was sutured to the bed of the wound with 5-0 nylon thread, as shown in Figure 2. Twenty underwent a surgical delay procedure on a cutaneous flap in the abdominal wall, and, simultaneously, an implant of a 
The effects of local nitroglycerin on the surgical delay procedure in prefabricated flaps by vascular implant in rats

femoral pedicle in the subdermal region of this flap. After surgery, the rats were placed in individual cages and given water and feed $\left(\right.$ Labina $\left.^{\circledR}\right)$ ad libitum.

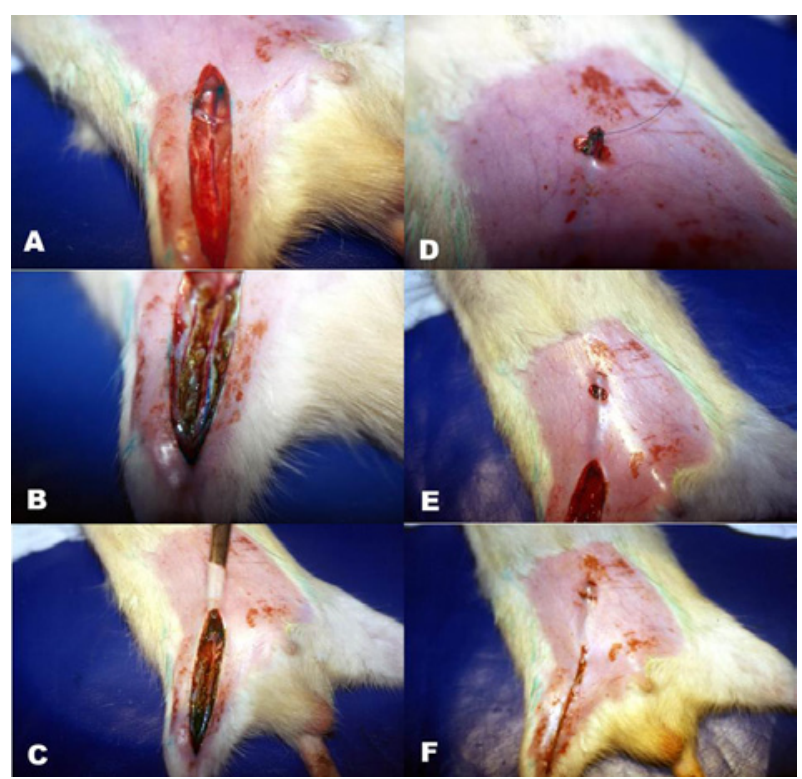

FIGURE 1 - Implant of femoral pedicle in abdominal skin. (A) Incision and visualization of pedicle; (B) Pedicle dissected with a layer of muscle; (C) Needle-holder placed through a tunnel to shift the stitch-placed pedicle; (D) Pedicle shifted after ligature and distal section; (E) Pedicle fixed $0.5 \mathrm{~cm}$ above the incision to form tunnel (arrow); (F) End of pedicle implant with incisions closed.

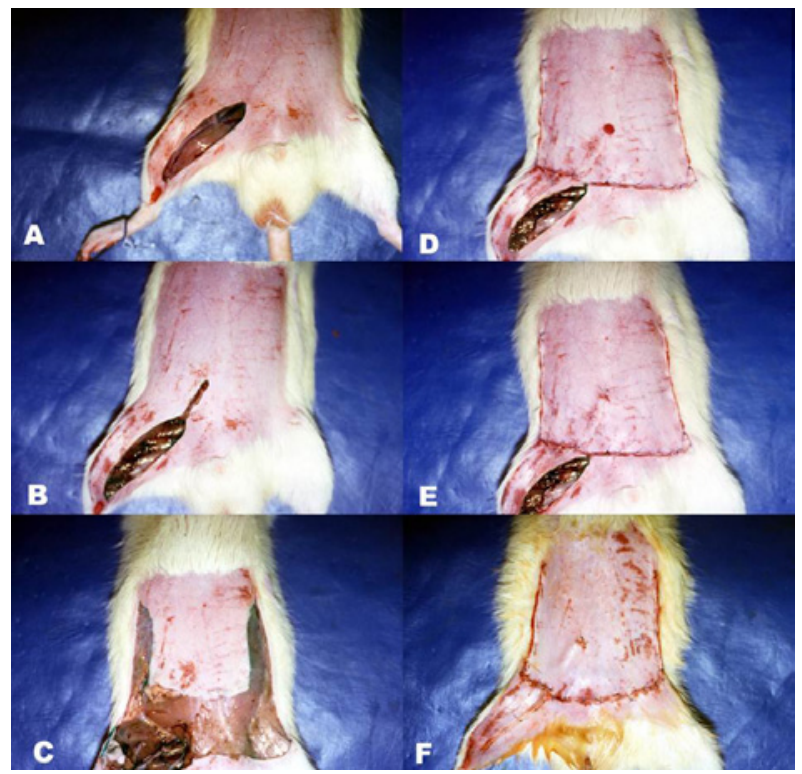

FIGURE 2 - Implant of pedicle in flap undergoing surgical delay procedure. (A) Dissected femoral pedicle; (B) Distally sectioned and shifted pedicle; (C) Surgical delay flap based on upper body: lateral and lower incisions and flap freed from bed; (D) Flap sutured to bed, showing opening of tunnel through which the pedicle passed; (E) Pedicle fixed to skin of flap; (F) End of implant of pedicle in surgical delay flap and suturing of incisions.

\section{Elevation of flap}

After three weeks of vascular implant, a cutaneous flap was elevated in an islet of the abdominal wall based on the implanted pedicle. The extension of this flap followed the same standards as those for the flaps undergoing surgical delay, complementing these with oblique incisions in the direction of the xiphoid appendix, from the side-stitching of each side. At this stage, the marked flap was photographed and the area obtained called the initial area (Ai). This raised flap was fed only by the implanted pedicle (Figure 3). The area around the vessels was dissected microscopically, as if it were a 'free flap'. After being elevated, the flap was sutured "in situ" with 5-0 nylon.

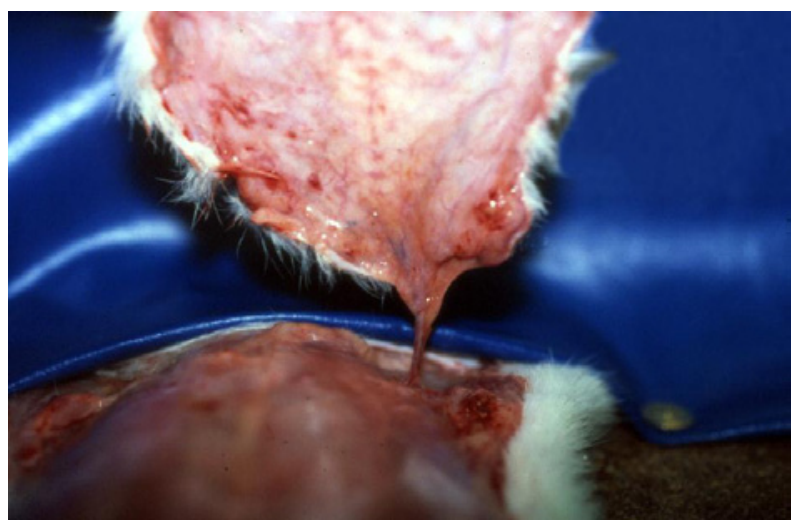

FIGURE 3 - Elevated flap after three weeks. Note that the flap is only fed by the implanted pedicle.

The nitroglycerin was applied to the rats in groups 3 and 4 by way of a Transdermic Therapeutic System; Nitroderm TTS ${ }^{\circledR}$ (Novartis Pharma Ag, Switzerland) applied to the center of the flap for seven days after surgery. This system contained $25 \mathrm{mg}$ of nitroglycerin on a $10 \mathrm{~cm}^{2}$ membrane, with an in vivo release rate of $5 \mathrm{mg}$ per 24 hours (Figure 4$)^{4}$.

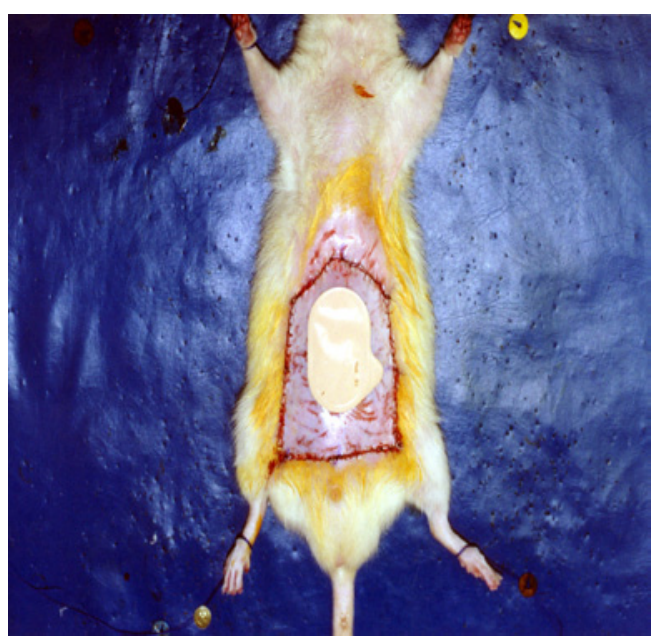

FIGURE 4 - Nitroderm STT, $25 \mathrm{mg}$ of nitroglycerin placed on the flap. 
At this time the animals were divided into four groups of ten. group 1, animals with flaps based on the implanted femoral pedicle in the subdermal region of the abdominal wall; group 2, animals underwent a surgical delay procedure with flaps based on the femoral pedicle implanted in the subdermal region of this flap; group 3, animals with flaps based on the femoral pedicle implanted in the subdermal region of the abdominal wall and the application of local nitroglycerin; group 4, animals underwent a surgical delay procedure with flaps based on the femoral pedicle implanted in the subdermal region of this flap and local nitroglycerin.

The Nitroderm STT was changed daily and kept in place for seven days using a $5 \mathrm{~cm}$-wide adhesive tape, applied without tension.

\section{Evaluation of area}

Seven days after having been left pedicled only by the implanted vessels, the flaps were photographed again to evaluate which areas were viable. The areas obtained during this stage were called final areas (Af).

The viable area for each animal was obtained by dividing the final area by the initial area, Af/Ai. The data for analysis were relative values, expressed as a percentage of the viable area in relation to the original area of the flap (Figure 5). For each animal, the final result for the area was taken to be the arithmetic mean of three measurements carried out by the same researcher.

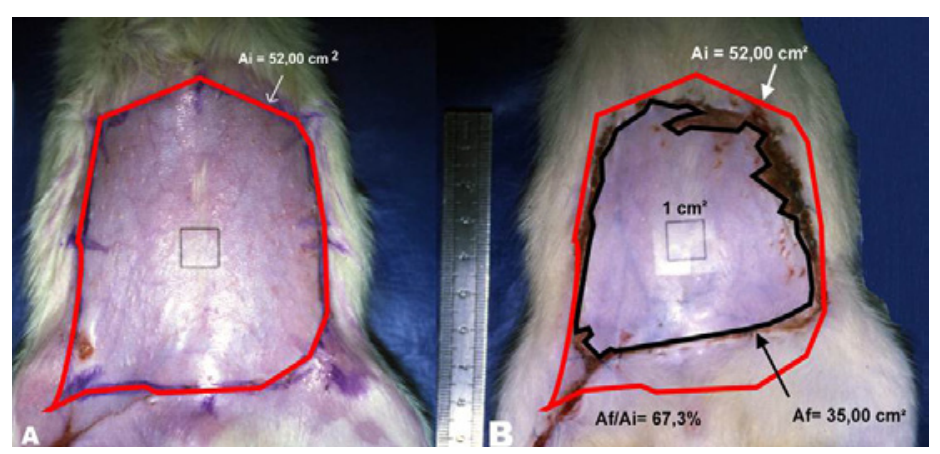

FIGURE 5 - Areas calculated using AutoCAD. (A) Initial area; (B) Final area.

\section{Histological study}

After photographing the final areas, the flaps were removed, fixed in 10\% formaldehyde and submitted to a histological study. A blood sample was collected from one animal in group 3 and one in group 4, at the end of the seventh day of use of the Nitroderm STT, to determine serum nitroglycerin levels. A separate study was carried out to determine these levels on the first, third and fifth days. A single sample was taken from each animal on the first, third and fifthdays of use of Nitroderm SST to determine the serum nitroglycerin levels during all the experiments.

The serum levels of nitroglycerin was determined by means of its principal metabolites (2- mononitrogycerin and 1,2-dinitroglicerin) using High Perfomance Liquid Cromatography - HPLC, at the UFPE's Department of industrial Chemistry.

In statistical analysis, the response variable was the relation between the final and the initial area. The values obtained were transformed into percentages. The comparison of the distributions of this relation between the groups was carried out using Kruskal-Wallis's non-parametric test, as the criteria for the use of the parametric ANOVA (Analysis of Variance) test were not considered satisfactory. The comparisons of the distributions of the relation between the final and initial area among the groups, following the Kruskal-Wallis test, were carried out using Bonferroni's multiple comparisons test. A level of significance of $5 \%$ was adopted for all tests.

The procedures were approved by the UFPE's Ethics Committee for Animal Experimentation and in accordance with the norms established by the Brazilian College for Animal Experimentation.

\section{Results}

No necrosis was observed in the flaps submitted to the first period of surgical delay. An increase in the caliber of the vessels available longitudinally in the flap, seen through the transparency of the skin, was found to occur systematically in the second stage of surgery in groups submitted to the surgical delay procedure.

Three weeks after implanting the pedicle, in Group 1 the average viable area of the flap was $8.9 \%$. In Group 2, an average of $49.4 \%$ of the flap was viable, compared to $8.4 \%$ in Group 3 and $1.1 \%$ in Group 4.

Table 1 shows the main statistics describing the initial area (Ai), the final area (Af) and the relation between the final and the initial area (Af/Ai), by experimental group. 
TABLE 1 - Main statistics describing initial area (Ai), final area (Af) and the relation between the initial and final area, by experimental group.

\begin{tabular}{|c|c|c|c|c|c|c|c|}
\hline & & \multicolumn{6}{|c|}{ Statistics Describing Areas $\mathbf{m m}^{2}$} \\
\hline Group & Variable & $\mathbf{n}$ & Mean & SD & Minimum & Median & Maximum \\
\hline \multirow{3}{*}{1} & $\mathrm{Ai}$ & 10 & 47.1 & 5.2 & 38.6 & \multirow{3}{*}{$\begin{array}{c}47.8 \\
2.2 \\
4.6\end{array}$} & 55.8 \\
\hline & $\mathrm{Ai}$ & 10 & 4.1 & 5.1 & 0.4 & & 16.5 \\
\hline & Af/Ai(\%) & 10 & 8.9 & 10.9 & 0.8 & & 35.3 \\
\hline \multirow{3}{*}{2} & $\mathrm{Ai}$ & 10 & 46.0 & 4.4 & 38.0 & \multirow{3}{*}{$\begin{array}{l}47.8 \\
23.4 \\
51.4\end{array}$} & 50.6 \\
\hline & $\mathrm{Ai}$ & 10 & 22.5 & 10.8 & 4.4 & & 36.0 \\
\hline & $\operatorname{Af} / \operatorname{Ai}(\%)$ & 10 & 49.4 & 23.2 & 8.8 & & 79.6 \\
\hline \multirow{3}{*}{3} & $\mathrm{Ai}$ & 10 & 37.6 & 7.6 & 27.1 & \multirow{3}{*}{$\begin{array}{c}37.3 \\
3.6 \\
7.9\end{array}$} & 47.0 \\
\hline & $\mathrm{Ai}$ & 10 & 3.0 & 2.5 & 0.0 & & 7.0 \\
\hline & Af/Ai(\%) & 10 & 8.4 & 8.0 & 0.0 & & 25.7 \\
\hline \multirow{3}{*}{4} & $\mathrm{Ai}$ & 10 & 35.7 & 9.6 & 28.3 & \multirow{3}{*}{$\begin{array}{c}32.7 \\
0.0 \\
0.0\end{array}$} & 58.5 \\
\hline & $\mathrm{Ai}$ & 10 & 0.4 & 0.8 & 0.0 & & 2.4 \\
\hline & Af/Ai(\%) & 10 & 1.1 & 2.5 & 0.0 & & 8.1 \\
\hline
\end{tabular}

The result of the Kruskal-Wallis test indicates that there were significant differences among the four experimental groups in terms of the distribution of values for $\mathrm{Af} / \mathrm{Ai}$ ( $\mathrm{p}<0.001$, Table 1). Bonferroni's multiple comparisons test reveals that the following groups exhibited a significantly different distribution of Af/Ai: Group 1 and Group 2 ( $\mathrm{p}=0.005)$; Group 1 and Group $4(\mathrm{p}=0.024)$; Group 2 and Group $3(\mathrm{p}=0.003)$; Group 2 and Group $4(\mathrm{p}<0.001)$. Figure 6 shows a representative sample of Af for each group.

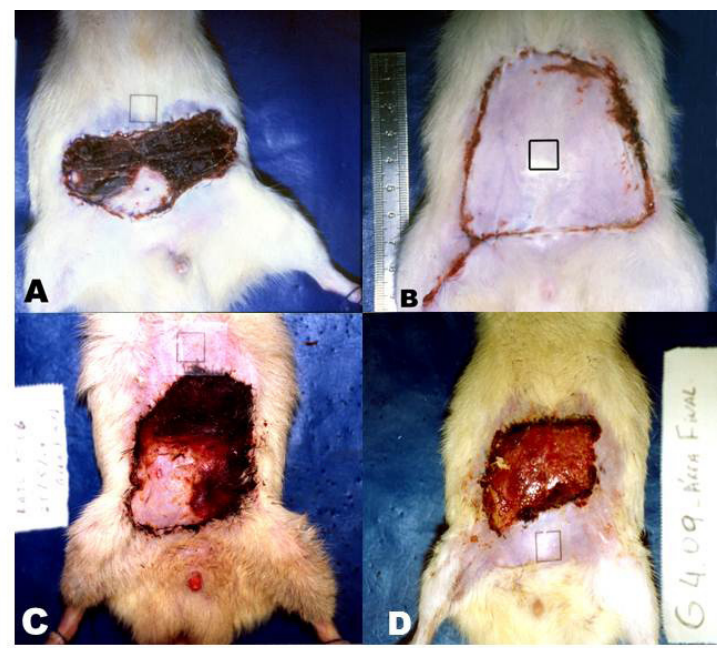

FIGURE 6 - Final areas of closed abdominal cutaneous flaps "in situ", seven days after being raised. (A) Flap with vascular implant without surgical delay procedure, Group 1; (B) Flap with vascular implant and surgical delay procedure, Group 2; (C) Flap with vascular implant without surgical delay procedure with application of Nitroderm STT nitroglycerin device, Group 3; (D) Flap with vascular implant and surgical delay procedure with application of Nitroderm STT nitroglycerin device, Group 4.
In the histological study, in the transition area between the preserved and ischemic skin the epidermis presented with coagulative necrosis and sometimes showed signs of erosion. There was subepidermal neutrophilic infiltrate which extended to the dermis at some points, with obstructed arteries. The dermis showed fibroblastic proliferation with areas of thick collagen. There were no cutaneous attachments or stretched skeletal muscle in the area corresponding to the epidermal necrosis. Granulation tissue was frequently observed at the base of the segment. These findings were identified in all groups.

The results of the studies of the efficiency of the medication delivery system (Nitoderm SST) and the systemic effect of the dose delivered indicated that the nitroglycerin was transported through the skin to the inner part of the flaps. HPLC was used to identify the metabolites of nitroglycerin in the plasma of all the animals submitted to treatment (Figure 7).

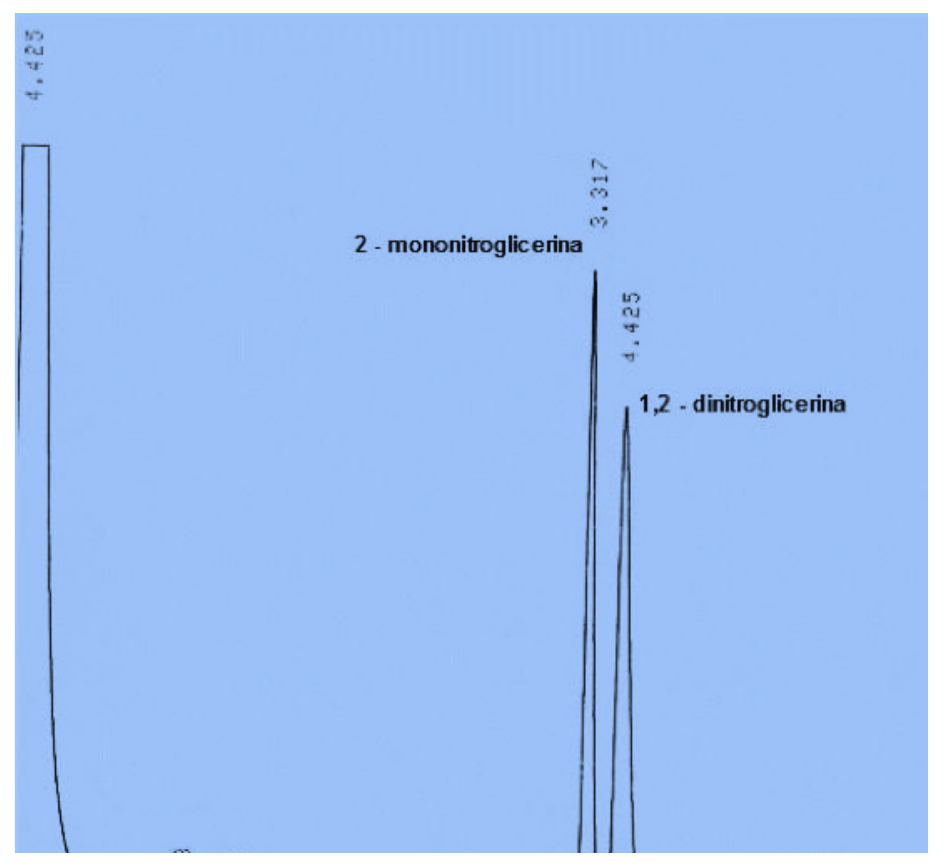

FIGURA 7 - High-performance liquid chromatogram of a sample of rat plasma, seven days after continuous use of nitroglycerin STT5. Mobile phase $=40 \%$ methanol, peak $1=2-$ mononitroglycerin; peak $2=1,2$ dinitroglycerin.

\section{Discussion}

The results presented in this study have shown that Although there was no significant decrease in the mean percentage of viable area in the groups undergoing the pedicle implant without surgical delay procedure (from $8.9 \%$ in Group 1 without nitroglycerin to $8.4 \%$ in Group 3 with local nitroglycerin), there was highly significant decrease in the groups where the flaps 
underwent surgical delay procedure (from $49.4 \%$ in Group 2 without nitroglycerin to $1.1 \%$ in Group 4 with nitroglycerin). The local venous vasodilator used (nitroglycerin) completely cancelled out the beneficial effect resulting from the surgical delay procedure applied to the prefabricated flap model.

Interpretation of the results of this study requires description of the mechanisms agreed to be important in the physiopathology of the failure of cutaneous flaps. Prime among this is the tissue damage that occurs in the ischemia-reperfusion mechanism. The large number of superoxide radicals produced as a by-product exceeds the normally low levels of endogenous superoxide dismutase enzyme (SOD), and the excess free radicals cause tissue damage through lipid peroxidation, which destroys the lipid layers of the cell walls and the intracellular organelles, culminating in tissue necrosis ${ }^{3}$.

In view of the tissue failure mechanism described above, Im et $a .^{3}$ suggest that the surgical delay procedure mechanism acts by maintaining the level of normal SOD enzyme in the distal portion of the flap undergoing surgical delay, while, according to these authors, this level would decrease in the acute flaps. There would thus be an increase in the viable area of flaps undergoing surgical delay procedure.

Another hypothesis regarding the physiopathology of the failure of cutaneous flaps focuses on the way the skin is fed at micro-circulatory level by an anastomotic web known as the subdermal plexus. In the skin, this plexus has a wealth of vessels that resemble the capillaries that connect the arterial to the venous system, which are called shunts. The areas of reduced blood flow, such as the distal portion of the cutaneous flap, the blood flow would be diverted through the pre-capillary shunts of low resistance, leading to ischemia and necrosis of the circumjacent tissue, since the blood would not reach the capillaries responsible for metabolic exchange, the nutrient vessels ${ }^{9}$.

Given this tissue failure mechanism, there are other authors who attempt to explain the phenomenon of surgical delay procedure $^{9-11}$. In the view of these authors, the partial reduction in the blood flow to the flap, during the surgical delay procedure, would lead to sympathectomy, as a result of the wearing down of the nerve fibers of the sympathetic nervous system, which run along and in the wall of the vessels. As a result, there would be a relaxing of the tonus in the shunts, increasing the blood flow through them. As this is a partial reduction in flow, there would also be sufficient pressure to ensure that blood arrived in the nutrient vessels to meet the tissue's metabolic requirements, although part of the blood flow to the skin would be diverted through the shunts, since these have lower resistance. This would explain the fact that there was no necrosis in the flaps in groups 2 and 4, which were subjected to a partial reduction in blood flow during the surgical delay procedure. After a number of days, as a result of denervation, the organism would move into a stage of hypersensitivity to the vasoactive amines that normally circulate in it, which would cause these shunts to close. During the second stage of surgery, after three weeks, the flap would be raised ready to be transferred. This new procedure would cause section of the nerve fibers, although not the opening of the shunts, since these would be closed due to the hypersensitivity to circulating vasoactive amines. The closing of the shunts would require greater quantities of blood to flow through the nutrient vessels, causing metabolic exchange, and thus improving the survival area of the flaps. According to this theory, therefore, the surgical delay procedure causes a closing of the shunts.

In the present study, flaps undergoing a surgical delay procedure were submitted to local nitroglycerin, whose action mechanism is well-known. The purpose was to investigate how the surgical delay procedure is capable of improving the survival area of the flaps.

As this is a potential venous vasodilator and in view of the hypothesis that surgical delay procedure acts by closing the shunts, there should be a considerable reduction in the survival area of flaps undergoing the surgical delay procedure. This should occur because, when flaps undergoing the surgical delay procedure are subjected to the action of a venous vasodilator, there is no closing of the shunts. Nitroglycerin favors the diversion of the blood flow the vessels of least resistance, considerably diminishing the blood flow to the nutrient vessels, hindering metabolic exchange at microcirculatory level and consequently allowing them to survive tissue necrosis.

If the surgical delay procedure acted by maintaining the levels of SOD enzyme in the distal portion of the flaps, it would supposedly have led to an increase in the survival area even greater than that observed in Group 2, where the flaps were submitted to surgical delay procedure without nitroglycerin. This would occur because nitroglycerin is capable of reducing vasoconstriction as a result of the adrenergic discharge, thereby lowering the production of free oxygen radicals and increasing the survival area of the flaps.

According to the results of the present study, the extent of survival area of the flaps subjected to surgical delay procedure alone (Group 2) decreased considerably when nitroglycerin was applied (Group 4). This could be explained by the theory that surgical delay procedure is caused by the closing of the shunts, since this and the subsequent inevitable flow of blood through the nutrient vessels would be responsible for the increase in the 
survival area observed in the flaps undergoing surgical delay procedure.

The experimental model used here, adds weight to the hypothesis that the shunts are involved in the physiology of the surgical delay procedure. The find out of a drug able to replace the surgical delay procedure would be important as to flap in threatening necrosis state, as to situation that surgical delay procedure can not be used. Further research is required to test new drugs that act selectively to close the shunts will be needed to confirm the results of this study and allow clinical trials of these medications to begin.

\section{Conclusion}

The local nitroglycerin did not lead to improvement in the survival area of flaps prefabricated for vascular implant and reduced it in flaps that had undergone a surgical delay procedure.

\section{References}

1. Nichter LS, Sobieski MW, Edgerton MT. Efficacy of topical nitroglycerin for random-pattern skin-flap salvage. Plast Reconstr Surg. 1985;75(6):847-52.

2. Rohrich RJ, Cherry GW, Spira M. Enhancement of skin-flap survival using nitroglycerin ointment. Plast Reconstr Surg. 1984;73(6):9438 .

3. Im MJ, Manson PN, Bulkley GB, Hoopes JE. Effects of superoxide dismutase and allopurinol on the survival of acute island skin flaps. Ann Surg. 1985;201(3):357-9.

4. Carpenter RJ, Angel MF, Mogan RF. Dimethyl sulfoxide increase the survival of primarily ischemic island skin flaps. Otolaryngol Head Neck Surg. 1994;110(2):228-31.

5. Hendel PM, Lilien DL, Buncke HJ. A study of the pharmacologic control of blood flow to scute skin flaps using xenon washout. Part I. Plast Reconstr Surg. 1983;71(3):387-98.

6. Rohrich RJ, Cherry GW, Spira M. Enhancement of skin-flap survival using nitroglycerin ointment. Plast Reconstr Surg. 1984;73(6):9438.

7. Sá JZ, Aguiar JLA, Morais J, Coelho ARB, Lopes SML, Melo CB. Área viável e vascularização, pós automização cirúrgica de retalho pré-fabricado por implante vascular em ratas. Acta Cir Bras. 2002;17(Supl. 1):39-42.

8. Cederna OS, Chang P, Pitted-Cuenod BM, Razaboni RM, Cram AE. The effect of the delay phenomenon on the vascularity of rabbit abdominal cutaneous island flaps. Plast Reconstr Surg. 1997;99(1):183-93.

9. Reinisch JF. The pathophysiology of skin flap circulation. The delay phenomenon. Plast Reconstr Surg. 1974;54(5):585-98.

10. Callegari PR, Ian Taylor G, Caddy CM, Minabe T. An anatomic review of the delay phenomenon: experimental studies. Plast Reconstr Surg. 1992;89(3):397-07.

11. Byun J, Constantinescu MA, Lee A, May Jr JW. Effects of delay procedures on vasculature and survival of arterialized venous flaps: an experimental study in rabbits. Plast Reconstr Surg. 1993;96(7):1650-59.

12. Dhar SC, Taylor GI. The delay phenomenon: the story unfolds. Br J
Plast Surg. 1999;104(7):2079-91.

13. Daniel RK, Kerringa CL. Principles and physiology of skin flap surgery. In: McCarthy, editor. Plastic Surgery Pensylvainia: W.B. Saunders Company; 1990. p.275-328.

14. Gribbe Ö, Lundeberg T, Samuelson EU, Wiklund NP. Nitric oxide synthase activity and endothelial ultrastructure in ischaemic skinflaps. Br J Plast Surg. 1997;50(7):486-90.

15. Han C, Gumbleton M, Lau DTW, Benet LZ. Improved gas chromatographic assay for the simultaneous determination of nitroglycerin and its mono-and dinitrate metabolites. J Chromatography. 1992;579(2):237-45.

16. Gabriel A, Porrino ML, Stephenson LLBS, Zamboni WA. Effect of L-arginine on leukocyte adhesion in ischemia-reperfusion injury. Platic Reconst Surg. 2004;113(6):1698-702

\section{Correspondence:}

Jairo Zacchê de Sá

Avenida Engenheiro Domingos Ferreira, 636/313

51111-050 Recife - PE Brasil

Tel.: (55 81)3467-5717

jzacche@surfix.com.br

Received: July 12, 2012

Review: September 13, 2012

Accepted: October 15, 2012

Conflict of interest: none

Financial source: none

${ }^{1}$ Research performed at Center for Experimental Surgery (CES), Department of Surgery, Federal University of Pernambuco (UFPE), Recife-PE, Brazil. Part of PhD degree thesis, Postgraduate Program in Surgery. Tutor: José Lamartine de Andrade Aguiar. 